\title{
Excess of Free Fatty Acids as a Cause of Metabolic Dysfunction in Skeletal Muscle
}

\author{
J. TUMOVA ${ }^{1}$, M. ANDEL ${ }^{1}$, J. TRNKA $^{1}$ \\ ${ }^{1}$ Department of Nutrition and Centre for Research on Diabetes, Metabolism and Nutrition, Third \\ Faculty of Medicine, Charles University in Prague, Prague, Czech Republic
}

Received January 13, 2015

Accepted May 28, 2015

On-line October 8, 2015

\begin{abstract}
Summary
Obesity is often associated with metabolic impairments in peripheral tissues. Evidence suggests an excess of free fatty acids (FFA) as one factor linking obesity and related pathological conditions and the impact of FFA overload on skeletal muscle metabolism is described herein. Obesity is associated with dysfunctional adipose tissue unable to buffer the flux of dietary lipids. Resulting increased levels and fluxes of plasma FFA lead to ectopic lipid deposition and lipotoxicity. FFA accumulated in skeletal muscle are associated with insulin resistance and overall cellular dysfunction. Mechanisms supposed to be involved in these conditions include the Randle cycle, intracellular accumulation of lipid metabolites, inflammation and mitochondrial dysfunction or mitochondrial stress. These mechanisms are described and discussed in the view of current experimental evidence with an emphasis on conflicting theories of decreased vs. increased mitochondrial fat oxidation associated with lipid overload. Since different types of FFA may induce diverse metabolic responses in skeletal muscle cells, this review also focuses on cellular mechanisms underlying the different action of saturated and unsaturated FFA.
\end{abstract}

\section{Key words}

Obesity • Free fatty acids $\bullet$ Skeletal muscle $\bullet$ Insulin resistance • Mitochondrial function

\section{Corresponding author}

J. Trnka, 3. LF UK, Ruská 87, 10000 Prague 10, Czech Republic. E-mail: jan.trnka@lf3.cuni.cz

\section{Obesity and circulating free fatty acids}

Overnutrition in combination with a sedentary lifestyle has led to a current epidemic of obesity. Although the etiology of obesity is multifactorial, main nutritional risk factors are an increase in total calorie intake and the consumption of high-fat diet (Astrup 2001). Obesity, especially with abdominal fat distribution, is frequently associated with metabolic alterations which predispose to the development of complications such as insulin resistance, type 2 diabetes or cardiovascular diseases (Després and Lemieux 2006). The question is what is the link between obesity and related metabolic complications.

The adipose tissue plays an important role in buffering the flux of dietary fat into the circulation in the postprandial period by suppressing the release of free fatty acids (FFA) into circulation and by increasing plasma triacylglycerol (TAG) clearance (Fig. 1). This buffering action limits an abnormal increase in plasma lipids and protects other tissues from exposure to excessive lipid fluxes (Frayn 2002). However, obesity is often associated with a dysfunctional adipose tissue, which is characterized by decreased insulin sensitivity, hypoxia, increased intracellular and systemic FFA flux, inflammation and the release of a variety of adipokines and inflammatory mediators into the circulation. Through FFA, adipokines and inflammatory molecules the dysfunctional adipose tissue communicates with peripheral tissues, such as liver, skeletal muscle or pancreatic $\beta$-cells and causes metabolic adverse effects 
(de Ferranti and Mozaffarian 2008). All these factors have been proposed to link obesity and related metabolic complications; this review, however, focuses on the role of FFA. The role of adipokines and inflammation has been reviewed elsewhere (Antuna-Puente et al. 2008, Esser et al. 2014).

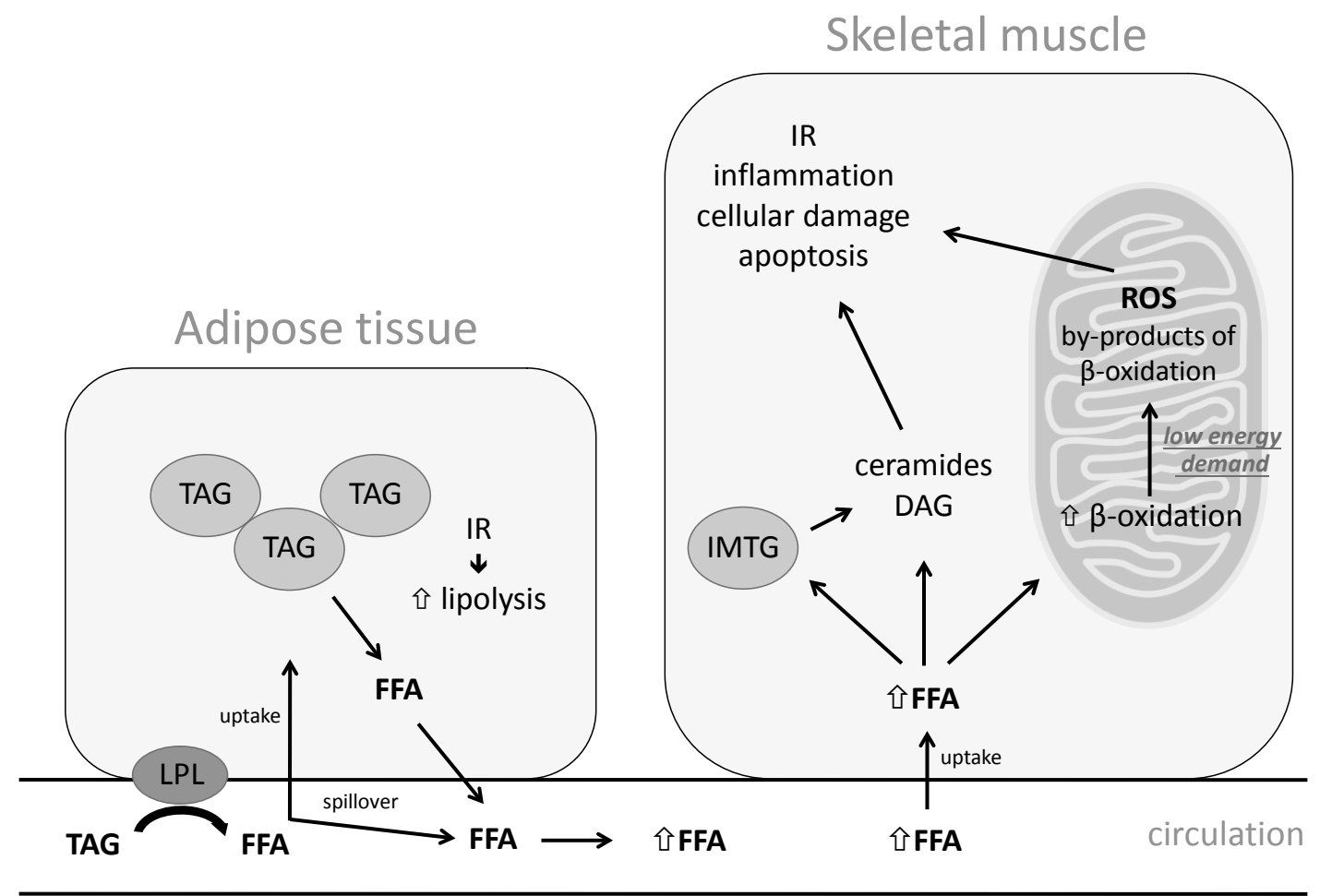

Fig. 1. A schematic view of obesity-associated, fatty acid-induced insulin resistance and metabolic dysfunction in skeletal muscle. An increased release of free fatty acids (FFA) from dysfunctional adipose tissue and a reduction in postprandial plasma triacylglycerols (TAG)/FFA clearance lead to higher circulating FFA levels/fluxes and higher uptake to skeletal muscle. FFA accumulated in skeletal muscle can be incorporated into intramyocellular TAG (IMTG) or oxidized in mitochondria. Excess FFA can then be converted to active lipid metabolites, such as ceramide and diacylglycerol (DAG). Oversupply of FFA drives an adaptive increase in mitochondrial $\beta$-oxidation, which, without an increase in energy demand, leads to incomplete fatty acid oxidation, increased redox pressure on the electron transport chain (ETC) and increased production of reactive oxygen species (ROS), with ensuing oxidative stress, development of insulin resistance (IR) and cellular damage.

There is another important source of plasma FFA besides lipolysis of TAG stores in adipose tissue. Uptake of fatty acids released from circulating TAG (esp. after a fat-rich meal) into the adipose tissue is not fully effective and a portion of fatty acids is released into the plasma in a process called, ,spillover“ (Fielding et al. 1996, Evans et al. 2002). In postprandial period this process can account for $40-50 \%$ of the total plasma FFA pool (Fielding et al. 1996). Dietary fat intake has therefore a significant influence on the composition of circulating FFA (Fig. 1). Obese subjects have been reported to have both an increased FFA release from dysfunctional adipose tissue and a reduction in postprandial plasma TAG/FFA clearance, with concomitant higher fasting and postprandial circulating FFA concentrations than lean subjects (Roust and Jensen 1993, Campbell et al. 1994, Nielsen et al. 2004).
A group of researchers has recently questioned the simple association between expanded adipose tissue mass and elevated systemic FFA levels (Karpe et al. 2011). They showed an evidence that fasting plasma FFA concentrations in obese people are not different from lean people although there is an increased FFA flux to nonadipose tissues in obese. Further investigations are therefore required to elucidate this relationship. Although an increased flux and accumulation of FFA in tissues not designed for fat storage, phenomena described as ectopic fat deposition, are generally accepted as crucial factors in obesity-associated complications.

\section{Systemic effects of FFA overload}

Excessive amounts of FFA accumulated in peripheral tissues have adverse effects on cellular 
signaling and functions, effects known as lipotoxicity (Schaffer 2003). The broadly studied and discussed pathological conditions associated with excess FFA are insulin resistance (IR) and impaired insulin-stimulated glucose disposal, the latter associated mainly with the skeletal muscle. These conditions are key components of type 2 diabetes and the metabolic syndrome and considerable research effort has been made to determine the role of excess FFA in their development.

To investigate the effects of high FFA fluxes on insulin sensitivity and other metabolic features in humans or animal models several experimental approaches have been used: lipid-heparin infusion, which predominately releases unsaturated fatty acids from exogenous TAG; prolonged fasting, which is accompanied by an increased release of fatty acids from endogenous lipid stores and a long-term consumption of high-fat diet. All approaches have some limitations, but in our opinion, the dietary intervention best reflects the physiological situation in obese individuals.

Experiments using lipid infusions and prolonged fasting demonstrated that increasing plasma FFA levels in lean individuals to levels seen in obese ones induced lipid accumulation in skeletal muscle and IR (Belfort et al. 2005, Hoeks et al. 2010). Dietary intervention studies with a consumption of high-fat diet also showed reduced insulin sensitivity and lipid accumulation in healthy people (Bachmann et al. 2001) and rodents (Turner et al. 2013). These findings indicate a close link between increased FFA levels/fluxes, ectopic lipid accumulation and IR in skeletal muscle. The role of FFA in the development of IR was supported by the observation that normalizing plasma FFA levels by pharmacological inhibition of lipolysis resulted in a normalization of insulin sensitivity and glucose tolerance in obese nondiabetic subjects and an improved insulin sensitivity in obese diabetic subjects (Santomauro et al. 1999).

\section{Impact of different composition dietary/plasma FFA}

Not only the amount but also the quality of dietary lipids is important in determining their effects in the body (Riccardi et al. 2004). Different types of FFA, defined by the degree of saturation and the length of carbon chain, may induce diverse metabolic responses in cells and tissues (Lottenberg et al. 2012).

The major types of fatty acids in the circulation and in the tissues of mammals are the long-chain (14-18 carbon atoms) and very-long-chain (20-26 carbon atoms) fatty acids with varying degrees of saturation (Turner $e t$ al. 2014). The most common FFA found in human plasma are saturated palmitic acid (16:0), monounsaturated oleic acid (18:1, n-9) and polyunsaturated linoleic acid (18:2, n-6) (Miwa 2002). A similar pattern is observed also in the plasma FFA pool of rodents (Koves et al. 2008). However, the composition of plasma and tissue FFA can significantly differ between individuals with respect to dietary fat intake.

According to the KANWU study, the total amount of fat influences insulin sensitivity only when it exceeds a threshold of $35-40 \%$ of daily energy intake. If the threshold is not exceeded, a critical factor in the induction of IR is not the amount of fat itself but its composition, i.e. the types of dietary FFA (Vessby et al. 2001, Riccardi et al. 2004). This and other intervention studies in humans (Lovejoy et al. 2002) indicated that saturated fat significantly worsens insulin sensitivity, whereas monounsaturated and polyunsaturated fats have a less pronounced effect or even improve insulin sensitivity. Saturated FFA have been shown to influence adiposity and associated metabolic dysfunction also in animal models, with particularly pro-inflammatory and insulin-antagonizing effects (Enos et al. 2013, Lionetti et al. 2014). These findings indicate that the composition of fat in lipid intervention studies, especially the amount of saturated/unsaturated FFA, should be considered as an important variable when investigating the metabolic impact of FFA.

\section{Effects of FFA overload on skeletal muscle metabolism}

Skeletal muscle is a key metabolic tissue affecting the metabolic state of the whole organism. It accounts for about $80 \%$ of postprandial insulinstimulated glucose disposal (DeFronzo et al. 1985) and is the main site of FFA utilization (Furler et al. 2000). FFA in skeletal muscle are stored in the form of intramyocellular TAG (IMTG) and represent an important source of energy (Fig. 1). Nevertheless, their excessive accumulation is linked to adverse effects - the subsequent impairment of insulin action in skeletal muscle is central to the pathogenesis of IR-associated diseases.

Several pathological mechanisms may play a role in FFA-induced IR and metabolic dysfunction in skeletal muscle. More than 50 years ago the concept of 
the glucose-fatty acid cycle was proposed by Randle and colleagues. Over the years many other mechanisms have been suggested, with central role of intracellular accumulation of lipid metabolites, inflammation, decreased mitochondrial oxidative capacity and oxidative stress.

\section{Randle cycle: competition between fatty acids and glucose}

Randle and colleagues were the first to propose a connection between elevated FFA concentrations and reduction in glucose disposal in muscle (Randle et al. 1963). Their study showed that an elevation in fatty acids supply to the diaphragm and isolated heart led to a competition of fatty acids with glucose as an energy substrate, so called glucose-fatty acid cycle, and an increased rate of fatty acid oxidation relative to carbohydrate oxidation. According to their model, an increased oxidation of muscle fatty acids produces increased levels of intracellular acetyl-CoA and citrate, which then inhibit the activities of enzymes involved in glucose utilization, pyruvate dehydrogenase and phosphofructokinase. The lowering of pyruvate oxidation and glycolysis would then result in glucose-6-phosphate accumulation, increased intracellular glucose content and reduction in glucose uptake (Lowell and Shulman 2005).

Subsequent studies have not fully confirmed Randle's hypothesis and have indicated that other mechanisms probably play a role in the FFA-induced impairment of glucose disposal in skeletal muscle, particularly defects in the insulin signaling pathways with concomitant decreased glucose uptake (Shulman 2000). However, the role of impaired metabolic flexibility, i.e. the ability to modify fuel oxidation in response to changes in nutrient availability, in skeletal muscle IR has been intensively studied (reviewed in Galgani et al. 2008), although no clear conclusion can be made from these studies.

\section{Intracellular accumulation of lipid metabolites, impaired insulin signaling and inflammation}

A number of studies in both animals and humans reported that an accumulation of IMTG in skeletal muscle strongly correlates with IR (Pan et al. 1997, Krssak et al. 1999); but this is true mainly in untrained individuals. Endurance-trained athletes are often extremely insulin sensitive despite a high content of IMTG and this observation has been referred to as the athlete's paradox (Goodpaster et al. 2001). It is now generally accepted that not IMTG accumulation itself but rather FFA-derived active lipid metabolites, such as diacylglycerol (DAG) and ceramide, are harmful for skeletal muscle (Fig. 1). The association between accumulation of active lipid species (DAG and/or ceramide) and the inhibition of insulin action was demonstrated in the skeletal muscle from obese insulin-resistant individuals, healthy people after a lipid infusion and in the skeletal muscle of high fat-fed mice (Itani et al. 2002, Amati et al. 2011, Turner et al. 2013). In vitro studies on skeletal muscle cells confirmed this association (Chavez and Summers 2003, Pickersgill et al. 2007). Specifically long-chain saturated FFA were shown to induce the synthesis of DAG and ceramide, with the most potent inducer being palmitic acid (Chavez and Summers 2003).

DAG and ceramide are active signaling molecules. Increased levels of these metabolites are involved in the activation of both conventional and novel protein kinases $\mathrm{C}$ (PKC) isoforms and c-Jun N-terminal kinases (JNK), which in turn impair insulin-stimulated signaling cascades leading to impaired glucose uptake. Furthermore, through IKB kinase $\beta$ (IKK $\beta$ ) and nuclear factor (NF)- $\kappa B$ they may activate inflammatory pathways with a concomitant production of pro-inflammatory cytokines, such as interleukin 6 (Coll et al. 2008, Eckardt et al. 2011). Saturated FFA can also directly stimulate inflammatory pathways through the activation of Tolllike receptor 4 (Senn 2006). Ceramides are known initiators of the apoptotic cascade (Gulbins 2003) and apoptosis induced by ceramide accumulation was reported in myotubes exposed to palmitic acid (Turpin et al. 2006).

Although recent animal and human studies strongly support the key role of DAG and the activation of PKC $\theta$ in the pathogenesis of lipid-induced muscle IR (Bruce et al. 2009, Szendroedi et al. 2014), there are also indications that an accumulation of DAG is not always associated with IR (Amati et al. 2011). Therefore, the role of this lipid species in muscle metabolism should be further examined, with emphasis on specific molecular species of DAG and their subcellular localization (Amati et al. 2011).

The accumulation of FFA and their metabolites in skeletal muscle may be the result of an imbalance between FFA supply (cellular uptake), storage in TAG (lipolysis and lipid synthesis) and mitochondrial oxidation. Intact insulin sensitivity despite high IMTG in 
endurance-trained subjects has been explained by a higher turnover rate of the IMTG pool and a more efficient coupling of lipolysis to mitochondrial fat oxidation, which may reduce the accumulation of lipotoxic intermediates (Moro et al. 2008). Studies in obese humans and high fat-fed rats revealed an enhanced transport of FFA into skeletal muscle associated with an increased IMTG content (Hegarty et al. 2002, Bonen et al. 2004). It was also shown that acute exercise or upregulation of TAG synthesis prevented lipid-induced impairments of insulin action in skeletal muscle and decreased DAG and ceramide accumulation (Liu et al. 2007, Schenk and Horowitz 2007). The role of mitochondrial fatty acid oxidation is, however, more controversial.

\section{Interaction of FFA with mitochondria}

Some features of mitochondrial dysfunction induced by FFA have been shown in cell culture as well as animal and human studies (Sparks et al. 2005, Brehm et al. 2006, Yuzefovych et al. 2012). One theory, which has been widely accepted for many years, considers mitochondrial impairment with decreased capacity to oxidize fat as a cause of cellular lipid accumulation with impaired insulin action and cellular dysfunction. However, recently this theory has been challenged and an increased fat oxidation with concomitant mitochondrial stress have instead been proposed as initial events leading to FFA-induced IR and cellular damage.

\section{Mitochondrial oxidative capacity}

Many different mitochondrial abnormalities have been reported in skeletal muscle of insulin-resistant obese and T2D subjects such as a deficiency of mitochondrial electron transport chain (ETC) (Ritov et al. 2010), decreased expression of genes involved in oxidative metabolism and mitochondrial biogenesis (Mootha et al. 2003, Patti et al. 2003), decreased fat oxidation (Kim et al. 2000) or less abundant mitochondria with a changed morphology (Kelley et al. 2002, Ritov et al. 2005). In vivo nuclear magnetic resonance studies revealed defects in mitochondrial oxidative phosphorylation with an accumulation of lipids in the skeletal muscle of lean, insulin-resistant offspring of T2D patients (Petersen et al. 2004) or elderly, insulinresistant individuals (Petersen et al. 2003). Feeding a high-fat diet to healthy young men or mice was reported to decrease muscle mRNA levels of genes involved in the oxidative phosphorylation (Sparks et al. 2005). Based on these and other studies it has been assumed that impaired mitochondrial oxidative capacity plays a pivotal role in intracellular accumulation of FFA and their metabolites and the development of IR in skeletal muscle (Morino et al. 2006). Evidence from cell culture and animal studies, which showed that increased oxidation of long-chain FFA in mitochondria, achieved by pharmaceutical or genetic approaches, reduced IMTG and lipid intermediates content and ameliorated IR in skeletal muscle in face of lipid overload (Tanaka et al. 2003, Krämer et al. 2005, Bruce et al. 2009) is in agreement with this hypothesis.

A number of studies in animals and humans, however, is incompatible with this concept and observed lipid-induced IR in skeletal muscle without an impairment of mitochondrial function (Brands et al. 2011, Hoeks et al. 2011, Fisher-Wellman et al. 2013) or with impairment which developed long time after the establishment of IR (Bonnard et al. 2008). In animal models, reduced oxidative phosphorylation due to a genetic modification of components of the ETC protected against the development of high-fat dietinduced IR and even increased insulin sensitivity in skeletal muscle (Pospisilik et al. 2007, Han et al. 2011). These findings argue against the concept that muscle lipid accumulation and IR are mediated by a deficiency in mitochondrial oxidative capacity. Another argument is based on the fact that skeletal muscle has a large respiratory reserve (spare capacity) to substantially increase substrate flux and ATP synthesis to meet a potential increase in energy demand. Most of the time, mitochondrial respiration in skeletal muscle is operating very far from its maximal capacity. Therefore it is questionable if moderately decreased mitochondrial content or enzyme activities can influence the rate of fat oxidation and lipid accumulation when energy requirements are relatively low (Muoio and Neufer 2012).

In fact, a few years ago, an alternative hypothesis connecting fatty acid oxidation to lipidinduced IR in skeletal muscle has been proposed, declaring excessive rather than reduced $\beta$-oxidation (Koves et al. 2008). This model proposed that lipid oversupply into the mitochondria drives an increase in mitochondrial $\beta$-oxidation that exceeds the capacity of the Krebs cycle and the ETC, leading to an incomplete fatty acid oxidation and intramitochondrial accumulation of by-products of oxidation, mitochondrial stress and 
impaired insulin action and cellular dysfunction. Experimental evidence confirmed that reduced fatty acid uptake and catabolism in mitochondria prevented lipidinduced IR in myotubes and skeletal muscle of high fatfed mice (Koves et al. 2008). Other studies documented elevated incomplete fat oxidation associated with impaired insulin signaling in cultured myocytes from obese subjects and myocytes from lean subjects exposed to excess FFA (Bell et al. 2010). Another animal studies also revealed an increased rather than decreased mitochondrial biogenesis and mitochondrial oxidative capacity in high fat-fed rodents (Turner et al. 2007, Hancock et al. 2008), pointing to an adaptation of lipid oxidation during lipid overload. Increased $\beta$-oxidation capacity in muscle mitochondria and lipid and acylcarnitine accumulation were observed also in skeletal muscle of diabetic rats compared to lean controls (Wessels et al. 2015).

Studies in cultured skeletal muscle cells demonstrated decreased generation of ATP (Hirabara et al. 2010), reduced oxidation of FFA and intracellular lipid accumulation (Pimenta et al. 2008) associated with IR after prolonged exposure to saturated FFA. However, acute exposure $(1 \mathrm{~h})$ of skeletal muscle cells to palmitic acid on the contrary induced $\beta$-oxidation (Fediuc et al. 2006). In another study transcriptional activation of pathways that increase fatty acid oxidation prevented DAG accumulation, inflammatory processes and development of IR induced by saturated FFA (Coll et al. 2010).

\section{Mitochondrial (oxidative) stress}

Mitochondria are not only major producers of ATP but are also a main source of reactive oxygen species (ROS), which are produced in ETC as byproducts of normal respiration (James et al. 2012). When ROS production is chronically increased and exceeds the capacity of antioxidant defence mechanisms, ROS cause damage to multiple cellular components, a state defined as an oxidative stress (Schieber and Chandel 2014).

Recently, production of ROS has emerged as an important link between excess FFA, mitochondria and insulin resistance (Fig. 1). Studies in high fat-fed rodents and obese people showed increased mitochondrial ROS production in skeletal muscle in association with IR and without signs of mitochondrial respiratory deficiency (Bonnard et al. 2008, Anderson et al. 2009, Lefort et al. 2010). Moreover attenuating mitochondrial ROS production protected against high-fat diet-induced IR
(Anderson et al. 2009, Hoehn et al. 2009). These studies suggest that an increased mitochondrial ROS production and altered cellular redox state are major determining factors in the loss of insulin sensitivity associated with high fat intake or obesity. Mitochondrial dysfunction is then considered to be a consequence of altered cellular metabolism and insulin resistance (Bonnard et al. 2008). This is in agreement with the above-mentioned theory of mitochondrial lipid overload with elevated $\beta$-oxidation, as an increased oxidation of FFA can lead to mitochondrial stress, increased ROS production and cellular damage.

Increased ROS production by saturated FFA was demonstrated also in cultured muscle cells (Lambertucci et al. 2008). Increased ROS production and oxidative damage of mitochondrial DNA were proposed as initial events leading to mitochondrial/cellular dysfunction, IR and apoptosis in myotubes (Yuzefovych et al. 2012, Barbosa et al. 2013). These effects were observed for saturated FFA and were abolished by targeting DNA repair enzymes into mitochondria (Yuzefovych et al. 2012) or by overexpressing catalase (Barbosa et al. 2013). ROS were also shown to activate stress kinases, such as JNK and IKK $\beta$, which have been linked to insulin resistance (BlochDamti and Bashan 2005) and this pathway may be a potential link between ROS and IR.

Several mechanisms of how the catabolism of long-chain FFA promotes mitochondrial ROS production have been proposed, such as excessive generation of reducing equivalents in $\beta$-oxidation, generation of intermediates and by-products of $\beta$-oxidation that can inhibit enzymes that detoxify ROS or direct inhibition of the ETC by these intermediates (Seifert et al. 2010). Exposure to excess long-chain FFA coupled with physical inactivity may lead to intensive mitochondrial ROS production. In such model, increased FFA availability increases flux through $\beta$-oxidation and provides a high supply of electrons to ETC, while a lack of physical activity and the consequent low ATP demand favor a high proton motive force, hyperpolarisation of mitochondrial membrane potential, inhibition of ETC and low respiration rate, i.e. conditions, which promote mitochondrial ROS formation (James et al. 2012).

Based on this evidence it is clear that interactions of FFA with mitochondria play an important role in cellular events induced by lipid overload. Although impaired mitochondrial oxidative capacity does not seem to be the underlying mechanism of lipid accumulation and IR, there are indications that 
mitochondrial number, morphology and function are compromised by excess FFA in cell cultures, animals and in obese subjects. These changes, however, seem to occur secondary to FFA-induced IR and alteration of cellular metabolism. ROS are currently accepted as early mediators responsible for FFA-induced IR and other metabolic abnormalities. Decreased mitochondrial content in the obese may also be a consequence of a lack of exercise (Hancock et al. 2008).

At this point it is difficult to conclude whether increasing fatty acid oxidation in mitochondria would be beneficial for muscle metabolism and insulin sensitivity or not. In this regard, we agree with a proposal of Muoio and colleagues that increasing the flux through $\beta$-oxidation could be beneficial only in parallel with increases energy expenditure (Muoio and Neufer 2012) which reduces the pressure on mitochondrial ETC and prevents excessive ROS production. In general, increased energy expenditure is an effective mechanism to maintain insulin sensitivity and other cellular functions in skeletal muscle exposed to lipid overload and exercise is a simple way to achieving it.

The role of mitochondria in lipid overload is one of the most controversial topics in this field. Studies often bring about contradictory results, which could in part come from differences in the populations studied or the type, duration and composition of lipid interventions. The methods of investigating mitochondrial function in skeletal muscle should also be carefully selected (in vivo measurements vs. in vitro measurements on permeabilized muscle fibers, primary cell cultures, tissue homogenates or isolated mitochondria) and if possible more than one aspect of mitochondrial function should be assessed to get a more complex view of metabolism. The term mitochondrial dysfunction should be better defined as it can cover a whole range of mitochondrial abnormalities, such as a decreased content and abnormal morphology of mitochondria, functional defects to oxidative phosphorylation machinery or changes in production and detoxification of ROS (Brand and Nicholls 2011). When evaluating cell culture studies, close attention must be paid to concentrations of FFA, which are often very high, and to the molar ratio of FFA and bovine serum albumin (BSA).

\section{Specific effects of unsaturated FFA}

Studies into mechanisms of FFA action in cultured muscle cells revealed that their effects are dependent on the type of FFA as was observed in animal and human studies, where composition of fat in the diet was an important factor in the induction of IR (Riccardi et al. 2004). Long-chain saturated palmitic acid induced insulin resistance, inflammation, mitochondrial damage, oxidative stress and apoptosis in skeletal muscle cells (Coll et al. 2008, Yuzefovych et al. 2012, Patková et al. 2014) whereas unsaturated FFA did not cause these changes and showed even protective effects against saturated FFA-induced damage. This protection has been observed mainly for monounsaturated oleic acid (Coll et al. 2008, Yuzefovych et al. 2010) and to some degree also for polyunsaturated FFA (Lam et al. 2011).

It has been proposed that unsaturated FFA protect cells against lipotoxicity by promoting FFA incorporation into TAG and thus decreasing their availability for metabolic conversions to active lipid metabolites and for pathways leading to cellular damage and apoptosis (Listenberger et al. 2003). Studies on muscle cells demonstrated that excess of palmitic acid was poorly incorporated into TAG and caused IR and apoptosis, in contrary to oleic acid, which was well incorporated into TAG and well tolerated. Moreover, oleic acid prevented deleterious action of palmitic acid by promoting its incorporation into TAG (Pickersgill et al. 2007, Henique et al. 2010). In animal studies, directing FFA into TAG by polyunsaturated fat diet or increased synthesis of TAG in transgenic mice prevented FFA-induced IR in skeletal muscle (Lee et al. 2006, Liu et al. 2007).

Polyunsaturated FFA have been shown to ameliorate saturated FFA-induced IR also by transcriptional activation of pathways that increase fat oxidation (Lam et al. 2011). Also other studies using oleic acid indicated that promoting mitochondrial fatty acid oxidation is a protective mechanism of unsaturated FFA against saturated FFA-induced damage (Coll et al. 2008, Henique et al. 2010).

Altogether, different effects of saturated and unsaturated FFA can be explained, at least partly, by their different metabolic fates in the cell. Beneficial effects of unsaturated FFA seem to be mediated through an increased intracellular FFA disposal by promoting their storage in TAG and/or oxidation in mitochondria. The latter, however, should be associated with an increased energy demand, because otherwise it would not be beneficial.

Unsaturated fatty acids have been reported to improve insulin sensitivity in animals and humans also by 
increasing the unsaturation of skeletal muscle membrane phospholipids (Storlien et al. 1991, Vessby et al. 1994). The saturation of membrane phospholipids influences membrane fluidity and the function of membrane proteins and may therefore affect physiological mechanisms involved in FFA and glucose uptake. The fatty acid spectrum in skeletal muscle phospholipids and TAG has been shown to reflect the composition of dietary fat (Andersson et al. 2002, Kien et al. 2011).

\section{Peroxisome proliferator-activated receptors}

Long-chain fatty acids can regulate energy metabolism in skeletal muscle cells through their binding to peroxisome proliferator-activated receptors (PPAR). These nuclear receptors act as transcription factors and control the expression of genes involved in glucose and lipid metabolism. Unsaturated FFA and their metabolites have been reported to be effective natural ligands and activators of these receptors, while short and long-chain saturated FFA are only weak activators (Forman et al. 1997, Kliewer et al. 1997).

Three isoforms of PPAR with tissue-specific expressions and functions were identified $-\operatorname{PPAR} \alpha, \beta / \delta$ and $\gamma$. PPAR $\delta$ is the most abundant isoform in skeletal muscle (Braissant et al. 1996). Both PPAR $\alpha$ and PPAR $\delta$ share some target genes involved in fatty acid and glucose metabolism (Muoio et al. 2002) and preferential/increased fat oxidation is an important metabolic effect of their activation, however, based on knock-out mice studies, PPAR $\delta$ seems to play a dominant role in skeletal muscle (Muoio et al. 2002, Schuler et al. 2006). PPAR $\delta$ is known to coordinate physiological adaptations of skeletal muscle in response to fasting and endurance exercise (Nakamura et al. 2014). The ablation of PPAR $\delta$ in skeletal muscle of mice led to obesity and diabetes (Schuler et al. 2006) and the activation of $\operatorname{PPAR} \delta$ with a synthetic agonist protected mice against high-fat diet-induced IR in skeletal muscle (Tanaka et al. 2003) and prevented FFA-induced inflammation and IR in muscle cells (Coll et al. 2010). Therefore PPAR $\delta$ has gained attention as a potential target for treatment of metabolic abnormalities in skeletal muscle associated with fat accumulation, mainly because of its favorable effects on fat oxidation and energy expenditure.

Interestingly, oral administration of the PPAR $\delta$ agonist to rodents worsened insulin-stimulated glucose transport in skeletal muscle (Cresser et al. 2010). Moreover, PPAR $\delta$-mediated increase in muscle mitochondrial oxidative capacity was observed in high fat-fed mice together with the establishment of IR (Hancock et al. 2008). Cell culture studies are also inconsistent regarding the involvement of PPAR $\delta$ in the protective effects of unsaturated FFA (Coll et al. 2008, Salvadó et al. 2013). Therefore the role of PPAR $\delta$ activation in conditions of lipid overload, whether by unsaturated FFA or a synthetic agonist, needs further study.

PPAR $\gamma$ is the least expressed isoform in skeletal muscle, however, its role in the maintenance of insulin sensitivity in skeletal muscle has been reported (Hevener et al. 2003, Hu et al. 2012) and should be therefore also further examined. One interesting question is how PPAR activity in skeletal muscle could be affected by FFA composition in the diet. It should be noted, however, that the regulation of PPAR is complex and likely depends not only on the availability of their ligands but also on the presence of different coregulators, phosphorylation status, etc. and these factors can further complicate the elucidation of their role.

\section{Concluding remarks}

While the association between FFA excess and metabolic dysfunction in skeletal muscle is well established, the exact cellular mechanisms of FFA action are still not clear and new theories are constantly appearing to explain this complex association.

Based on current experimental evidence we may conclude that excess FFA cause detrimental effects in skeletal muscle through multiple factors and pathways (Fig. 1). A principal role seems to be played by an increased content of FFA-derived active lipid species and alterations of mitochondrial respiration leading to changes of cellular redox state. Effective coordination of several processes and pathways, such as FFA cellular uptake, storage in TAG and efficient mitochondrial oxidation seems to be particularly important to prevent FFA-induced deleterious effects. Similarly, the balance between individual metabolic pathways may play an important role. The most important factor would then indisputably be the balance between energy supply and demand.

The type of FFA also seems to be of a great importance in determining their action in skeletal muscle cells and therefore further studies exploring how the fatty acid composition in diet or experimental lipid interventions affects skeletal muscle metabolism, such as mitochondrial function, insulin sensitivity or redox status, 
especially in humans, are required.

\section{Conflict of Interest}

There is no conflict of interest.

\section{Acknowledgements}

This work was supported by the research project of Grant Agency of Charles University GAUK 661912, PRVOUK-P31 and Charles University Centre for the Study of Energy Metabolism (UNCE 204015/2012).

\section{References}

AMATI F, DUBÉ JJ, ALVAREZ-CARNERO E, EDREIRA MM, CHOMENTOWSKI P, COEN PM, SWITZER GE, BICKEL PE, STEFANOVIC-RACIC M, TOLEDO FG, GOODPASTER BH: Skeletal muscle triglycerides, diacylglycerols, and ceramides in insulin resistance: another paradox in endurance-trained athletes? Diabetes 60: 2588-2597, 2011.

ANDERSON EJ, LUSTIG ME, BOYLE KE, WOODLIEF TL, KANE DA, LIN CT, PRICE JW, KANG L, RABINOVITCH PS, SZETO HH, HOUMARD JA, CORTRIGHT RN, WASSERMAN DH, NEUFER PD: Mitochondrial $\mathrm{H}_{2} \mathrm{O}_{2}$ emission and cellular redox state link excess fat intake to insulin resistance in both rodents and humans. J Clin Invest 119: 573-581, 2009.

ANDERSSON A, NÄLSÉN C, TENGBLAD S, VESSBY B: Fatty acid composition of skeletal muscle reflects dietary fat composition in humans. Am J Clin Nutr 76: 1222-1229, 2002.

ANTUNA-PUENTE B, FEVE B, FELLAHI S, BASTARD JP. Adipokines: the missing link between insulin resistance and obesity. Diabetes Metab 34: 2-11, 2008.

ASTRUP A: Healthy lifestyles in Europe: prevention of obesity and type II diabetes by diet and physical activity. Public Health Nutr 4: 499-515, 2001.

BACHMANN OP, DAHL DB, BRECHTEL K, MACHANN J, HAAP M, MAIER T, LOVISCACH M, STUMVOLL M, CLAUSSEN CD, SCHICK F, HÄRING HU, JACOB S: Effects of intravenous and dietary lipid challenge on intramyocellular lipid content and the relation with insulin sensitivity in humans. Diabetes 50: 2579-2584, 2001.

BARBOSA MR, SAMPAIO IH, TEODORO BG, SOUSA TA, ZOPPI CC, QUEIROZ AL, PASSOS MA, ALBERICI LC, TEIXEIRA FR, MANFIOLLI AO, BATISTA TM, CAPPELLI AP, REIS RI, FRASSON D, KETTELHUT IC, PARREIRAS-E-SILVA LT, COSTA-NETO CM, CARNEIRO EM, CURI R, SILVEIRA LR: Hydrogen peroxide production regulates the mitochondrial function in insulin resistant muscle cells: effect of catalase overexpression. Biochim Biophys Acta 1832: 1591-1604, 2013.

BELFORT R, MANDARINO L, KASHYAP S, WIRFEL K, PRATIPANAWATR T, BERRIA R, DEFRONZO RA, CUSI K: Dose-response effect of elevated plasma free fatty acid on insulin signaling. Diabetes 54: 1640-1648, 2005.

BELL JA, REED MA, CONSITT LA, MARTIN OJ, HAYNIE KR, HULVER MW, MUOIO DM, DOHM GL: Lipid partitioning, incomplete fatty acid oxidation, and insulin signal transduction in primary human muscle cells: effects of severe obesity, fatty acid incubation, and fatty acid translocase/CD36 overexpression. $J$ Clin Endocrinol Metab 95: 3400-3410, 2010.

BLOCH-DAMTI A, BASHAN N. Proposed mechanisms for the induction of insulin resistance by oxidative stress: Antioxid Redox Signal 7: 1553-1567, 2005.

BONEN A, PAROLIN ML, STEINBERG GR, CALLES-ESCANDON J, TANDON NN, GLATZ JF, LUIKEN JJ, HEIGENHAUSER GJ, DYCK DJ: Triacylglycerol accumulation in human obesity and type 2 diabetes is associated with increased rates of skeletal muscle fatty acid transport and increased sarcolemmal FAT/CD36: FASEB J 18: 1144-1146, 2004.

BONNARD C, DURAND A, PEYROL S, CHANSEAUME E, CHAUVIN MA, MORIO B, VIDAL H, RIEUSSET J: Mitochondrial dysfunction results from oxidative stress in the skeletal muscle of diet-induced insulin-resistant mice. J Clin Invest 118: 789-800, 2008. 
BRAISSANT O, FOUFELLE F, SCOTTO C, DAUÇA M, WAHLI W: Differential expression of peroxisome proliferator-activated receptors (PPARs): tissue distribution of PPAR-alpha, -beta, and -gamma in the adult rat. Endocrinology 137: 354-366, 1996.

BRAND MD, NICHOLLS DG: Assessing mitochondrial dysfunction in cells: Biochem J 435: 297-312, 2011.

BRANDS M, HOEKS J, SAUERWEIN HP, ACKERMANS MT, OUWENS M, LAMMERS NM, VAN DER PLAS MN, SCHRAUWEN P, GROEN AK, SERLIE MJ: Short-term increase of plasma free fatty acids does not interfere with intrinsic mitochondrial function in healthy young men. Metabolism 60: 1398-1405, 2011.

BREHM A, KRSSAK M, SCHMID AI, NOWOTNY P, WALDHÄUSL W, RODEN M: Increased lipid availability impairs insulin-stimulated ATP synthesis in human skeletal muscle. Diabetes 55: 136-140, 2006.

BRUCE CR, HOY AJ, TURNER N, WATT MJ, ALLEN TL, CARPENTER K, COONEY GJ, FEBBRAIO MA, KRAEGEN EW: Overexpression of carnitine palmitoyltransferase-1 in skeletal muscle is sufficient to enhance fatty acid oxidation and improve high-fat diet-induced insulin resistance. Diabetes 58: 550-558, 2009.

CAMPBELL PJ, CARLSON MG, NURJHAN N: Fat metabolism in human obesity: Am J Physiol 266: E600-E605, 1994.

CHAVEZ JA, SUMMERS SA: Characterizing the effects of saturated fatty acids on insulin signaling and ceramide and diacylglycerol accumulation in 3T3-L1 adipocytes and C2C12 myotubes. Arch Biochem Biophys 419: 101$109,2003$.

COLL T, EYRE E, RODRÍGUEZ-CALVO R, PALOMER X, SÁNCHEZ RM, MERLOS M, LAGUNA JC, VÁZQUEZ-CARRERA M: Oleate reverses palmitate-induced insulin resistance and inflammation in skeletal muscle cells. J Biol Chem 283: 11107-11116, 2008.

COLL T, ALVAREZ-GUARDIA D, BARROSO E, GÓMEZ-FOIX AM, PALOMER X, LAGUNA JC, VÁZQUEZCARRERA M: Activation of peroxisome proliferator-activated receptor-\{delta\} by GW501516 prevents fatty acid-induced nuclear factor-\{kappa $\} \mathrm{B}$ activation and insulin resistance in skeletal muscle cells. Endocrinology 151: 1560-1569, 2010.

CRESSER J, BONEN A, CHABOWSKI A, STEFANYK LE, GULLI R, RITCHIE I, DYCK DJ: Oral administration of a PPAR-delta agonist to rodents worsens, not improves, maximal insulin-stimulated glucose transport in skeletal muscle of different fibers. Am J Physiol Regul Integr Comp Physiol 299: R470-R479, 2010.

DE FERRANTI S, MOZAFFARIAN D: The perfect storm: obesity, adipocyte dysfunction, and metabolic consequences. Clin Chem 54: 945-955, 2008.

DEFRONZO RA, GUNNARSSON R, BJÖRKMAN O, OLSSON M, WAHREN J: Effects of insulin on peripheral and splanchnic glucose metabolism in noninsulin-dependent (type II) diabetes mellitus. $J$ Clin Invest 76: 149-155, 1985.

DESPRÉS JP, LEMIEUX I: Abdominal obesity and metabolic syndrome. Nature 444: 881-887, 2006.

ECKARDT K, TAUBE A, ECKEL J: Obesity-associated insulin resistance in skeletal muscle: role of lipid accumulation and physical inactivity. Rev Endocr Metab Disord 12: 163-172, 2011.

ENOS RT, DAVIS JM, VELÁZQUEZ KT, MCCLELLAN JL, DAY SD, CARNEVALE KA, MURPHY EA: Influence of dietary saturated fat content on adiposity, macrophage behavior, inflammation, and metabolism: composition matters. J Lipid Res 54: 152-163, 2013.

ESSER N, LEGRAND-POELS S, PIETTE J, SCHEEN AJ, PAQUOT N: Inflammation as a link between obesity, metabolic syndrome and type 2 diabetes. Diabetes Res Clin Pract 105: 141-150, 2014.

EVANS K, BURDGE GC, WOOTTON SA, CLARK ML, FRAYN KN: Regulation of dietary fatty acid entrapment in subcutaneous adipose tissue and skeletal muscle. Diabetes 51: 2684-2690, 2002.

FEDIUC S, GAIDHU MP, CEDDIA RB: Regulation of AMP-activated protein kinase and acetyl-CoA carboxylase phosphorylation by palmitate in skeletal muscle cells. J Lipid Res 47: 412-420, 2006.

FIELDING BA, CALLOW J, OWEN RM, SAMRA JS, MATTHEWS DR, FRAYN KN: Postprandial lipemia: the origin of an early peak studied by specific dietary fatty acid intake during sequential meals. Am J Clin Nutr 63: 36-41, 1996.

FISHER-WELLMAN KH, WEBER TM, CATHEY BL, BROPHY PM, GILLIAM LA, KANE CL, MAPLES JM, GAVIN TP, HOUMARD JA, NEUFER PD: Mitochondrial respiratory capacity and content are normal in young insulin-resistant obese humans. Diabetes 63: 132-141, 2014. 
FORMAN BM, CHEN J, EVANS RM: Hypolipidemic drugs, polyunsaturated fatty acids, and eicosanoids are ligands for peroxisome proliferator-activated receptors alpha and delta. Proc Natl Acad Sci U S A 94: 4312-4317, 1997.

FRAYN KN: Adipose tissue as a buffer for daily lipid flux. Diabetologia 45: 1201-1210, 2002.

FURLER SM, COONEY GJ, HEGARTY BD, LIM-FRASER MY, KRAEGEN EW, OAKES ND: Local factors modulate tissue-specific NEFA utilization: assessment in rats using 3H-(R)-2-bromopalmitate. Diabetes 49 : 1427-1433, 2000.

GALGANI JE, MORO C, RAVUSSIN E: Metabolic flexibility and insulin resistance. Am J Physiol Endocrinol Metab 295: E1009-E1017, 2008.

GOODPASTER BH, HE J, WATKINS S, KELLEY DE: Skeletal muscle lipid content and insulin resistance: evidence for a paradox in endurance-trained athletes. J Clin Endocrinol Metab 86: 5755-5761, 2001.

GULBINS E: Regulation of death receptor signaling and apoptosis by ceramide. Pharmacol Res 47: 393-399, 2003.

HAN DH, HANCOCK CR, JUNG SR, HIGASHIDA K, KIM SH, HOLLOSZY JO: Deficiency of the mitochondrial electron transport chain in muscle does not cause insulin resistance. PLoS One 6: e19739, 2011.

HANCOCK CR, HAN DH, CHEN M, TERADA S, YASUDA T, WRIGHT DC, HOLLOSZY JO: High-fat diets cause insulin resistance despite an increase in muscle mitochondria. Proc Natl Acad Sci U S A 105: 7815-7820, 2008.

HEGARTY BD, COONEY GJ, KRAEGEN EW, FURLER SM: Increased efficiency of fatty acid uptake contributes to lipid accumulation in skeletal muscle of high fat-fed insulin-resistant rats. Diabetes 51: 1477-1484, 2002.

HENIQUE C, MANSOURI A, FUMEY G, LENOIR V, GIRARD J, BOUILLAUD F, PRIP-BUUS C, COHEN I: Increased mitochondrial fatty acid oxidation is sufficient to protect skeletal muscle cells from palmitateinduced apoptosis. J Biol Chem 285: 36818-36827, 2010.

HEVENER AL, HE W, BARAK Y, LE J, BANDYOPADHYAY G, OLSON P, WILKES J, EVANS RM, OLEFSKY J: Muscle-specific Pparg deletion causes insulin resistance. Nat Med 9: 1491-1497, 2003.

HIRABARA SM, CURI R, MAECHLER P: Saturated fatty acid-induced insulin resistance is associated with mitochondrial dysfunction in skeletal muscle cells. J Cell Physiol 222: 187-194, 2010.

HOEHN KL, SALMON AB, HOHNEN-BEHRENS C, TURNER N, HOY AJ, MAGHZAL GJ, STOCKER R, VAN REMMEN H, KRAEGEN EW, COONEY GJ, RICHARDSON AR, JAMES DE: Insulin resistance is a cellular antioxidant defense mechanism. Proc Natl Acad Sci U S A 106: 17787-17792, 2009.

HOEKS J, VAN HERPEN NA, MENSINK M, MOONEN-KORNIPS E, VAN BEURDEN D, HESSELINK MK, SCHRAUWEN P: Prolonged fasting identifies skeletal muscle mitochondrial dysfunction as consequence rather than cause of human insulin resistance. Diabetes 59: 2117-2125, 2010.

HOEKS J, WILDE JD, HULSHOF MF, BERG SA, SCHAART G, DIJK KW, SMIT E, MARIMAN EC: High fat dietinduced changes in mouse muscle mitochondrial phospholipids do not impair mitochondrial respiration despite insulin resistance. PLoS One 6: e27274, 2011.

HU S, YAO J, HOWE AA, MENKE BM, SIVITZ WI, SPECTOR AA, NORRIS AW: Peroxisome proliferatoractivated receptor $\gamma$ decouples fatty acid uptake from lipid inhibition of insulin signaling in skeletal muscle. Mol Endocrinol 26: 977-988, 2012.

ITANI SI, RUDERMAN NB, SCHMIEDER F, BODEN G: Lipid-induced insulin resistance in human muscle is associated with changes in diacylglycerol, protein kinase C, and IkappaB-alpha. Diabetes 51: 2005-2011, 2002.

JAMES AM, COLLINS Y, LOGAN A, MURPHY MP: Mitochondrial oxidative stress and the metabolic syndrome. Trends Endocrinol Metab 23: 429-434, 2012.

KARPE F, DICKMANN JR, FRAYN KN: Fatty acids, obesity, and insulin resistance: time for a reevaluation. Diabetes 60: 2441-2449, 2011.

KELLEY DE, HE J, MENSHIKOVA EV, RITOV VB: Dysfunction of mitochondria in human skeletal muscle in type 2 diabetes. Diabetes 51: 2944-2950, 2002.

KIEN CL, EVERINGHAM KI, D STEVENS R, FUKAGAWA NK, MUOIO DM: Short-term effects of dietary fatty acids on muscle lipid composition and serum acylcarnitine profile in human subjects. Obesity (Silver Spring) 19: 305-311, 2011. 
KIM JY, HICKNER RC, CORTRIGHT RL, DOHM GL, HOUMARD JA: Lipid oxidation is reduced in obese human skeletal muscle. Am J Physiol Endocrinol Metab 279: E1039-E1044, 2000.

KLIEWER SA, SUNDSETH SS, JONES SA, BROWN PJ, WISELY GB, KOBLE CS, DEVCHAND P, WAHLI W, WILLSON TM, LENHARD JM, LEHMANN JM: Fatty acids and eicosanoids regulate gene expression through direct interactions with peroxisome proliferator-activated receptors alpha and gamma. Proc Natl Acad Sci U S A 94: 4318-4323, 1997.

KOVES TR, USSHER JR, NOLAND RC, SLENTZ D, MOSEDALE M, ILKAYEVA O, BAIN J, STEVENS R, DYCK JR, NEWGARD CB, LOPASCHUK GD, MUOIO DM: Mitochondrial overload and incomplete fatty acid oxidation contribute to skeletal muscle insulin resistance. Cell Metab 7: 45-56, 2008.

KRÄMER DK, AL-KHALILI L, PERRINI S, SKOGSBERG J, WRETENBERG P, KANNISTO K, WALLBERGHENRIKSSON H, EHRENBORG E, ZIERATH JR, KROOK A: Direct activation of glucose transport in primary human myotubes after activation of peroxisome proliferator-activated receptor delta. Diabetes 54: 1157-1163, 2005.

KRSSAK M, FALK PETERSEN K, DRESNER A, DIPIETRO L, VOGEL SM, ROTHMAN DL, RODEN M, SHULMAN GI: Intramyocellular lipid concentrations are correlated with insulin sensitivity in humans: a $1 \mathrm{H}$ NMR spectroscopy study. Diabetologia 42: 113-116, 1999.

LAM YY, HATZINIKOLAS G, WEIR JM, JANOVSKÁ A, MCAINCH AJ, GAME P, MEIKLE PJ, WITTERT GA: Insulin-stimulated glucose uptake and pathways regulating energy metabolism in skeletal muscle cells: the effects of subcutaneous and visceral fat, and long-chain saturated, n-3 and n-6 polyunsaturated fatty acids. Biochim Biophys Acta 1811: 468-475, 2011.

LAMBERTUCCI RH, HIRABARA SM, SILVEIRA LR, LEVADA-PIRES AC, CURI R, PITHON-CURI TC: Palmitate increases superoxide production through mitochondrial electron transport chain and NADPH oxidase activity in skeletal muscle cells. J Cell Physiol 216: 796-804, 2008.

LEE JS, PINNAMANENI SK, EO SJ, CHO IH, PYO JH, KIM CK, SINCLAIR AJ, FEBBRAIO MA, WATT MJ: Saturated, but not n-6 polyunsaturated, fatty acids induce insulin resistance: role of intramuscular accumulation of lipid metabolites. J Appl Physiol (1985) 100: 1467-1474, 2006.

LEFORT N, GLANCY B, BOWEN B, WILLIS WT, BAILOWITZ Z, DE FILIPPIS EA, BROPHY C, MEYER C, HØJLUND K, YI Z, MANDARINO LJ: Increased reactive oxygen species production and lower abundance of complex I subunits and carnitine palmitoyltransferase 1B protein despite normal mitochondrial respiration in insulin-resistant human skeletal muscle. Diabetes 59: 2444-2452, 2010.

LIONETTI L, MOLLICA MP, SICA R, DONIZZETTI I, GIFUNI G, PIGNALOSA A, CAVALIERE G, PUTTI R: Differential effects of high-fish oil and high-lard diets on cells and cytokines involved in the inflammatory process in rat insulin-sensitive tissues. Int J Mol Sci 15: 3040-2063, 2014.

LISTENBERGER LL, HAN X, LEWIS SE, CASES S, FARESE RV Jr, ORY DS, SCHAFFER JE: Triglyceride accumulation protects against fatty acid-induced lipotoxicity. Proc Natl Acad Sci U S A 100: 3077-3082, 2003.

LIU L, ZHANG Y, CHEN N, SHI X, TSANG B, YU YH: Upregulation of myocellular DGAT1 augments triglyceride synthesis in skeletal muscle and protects against fat-induced insulin resistance. J Clin Invest 117: 1679-1689, 2007.

LOTTENBERG AM, AFONSO MDS, LAVRADOR MSF, MACHADO RM, NAKANDAKARE ER: The role of dietary fatty acids in the pathology of metabolic syndrome. J Nutr Biochem 23: 1027-1040, 2012.

LOVEJOY JC, SMITH SR, CHAMPAGNE CM, MOST MM, LEFEVRE M, DELANY JP, DENKINS YM, ROOD JC, VELDHUIS J, BRAY GA: Effects of diets enriched in saturated (palmitic), monounsaturated (oleic), or trans (elaidic) fatty acids on insulin sensitivity and substrate oxidation in healthy adults. Diabetes Care 25: 1283$1288,2002$.

LOWELL BB, SHULMAN GI: Mitochondrial dysfunction and type 2 diabetes. Science 307: 384-387, 2005.

MIWA H: High-performance liquid chromatographic determination of free fatty acids and esterified fatty acids in biological materials as their 2-nitrophenylhydrazides. Anal Chim Acta 465: 237-255, 2002. 
MOOTHA VK, LINDGREN CM, ERIKSSON KF, SUBRAMANIAN A, SIHAG S, LEHAR J, PUIGSERVER P, CARLSSON E, RIDDERSTRÅLE M, LAURILA E, HOUSTIS N, DALY MJ, PATTERSON N, MESIROV JP, GOLUB TR, TAMAYO P, SPIEGELMAN B, LANDER ES, HIRSCHHORN JN, ALTSHULER D, GROOP LC: PGC-1alpha-responsive genes involved in oxidative phosphorylation are coordinately downregulated in human diabetes. Nat Genet 34: 267-273, 2003.

MORINO K, PETERSEN KF, SHULMAN GI: Molecular mechanisms of insulin resistance in humans and their potential links with mitochondrial dysfunction. Diabetes 55 (Suppl 2): S9-S15, 2006.

MORO C, BAJPEYI S, SMITH SR: Determinants of intramyocellular triglyceride turnover: implications for insulin sensitivity. Am J Physiol Endocrinol Metab 294: E203-E213, 2008.

MUOIO DM, MACLEAN PS, LANG DB, LI S, HOUMARD JA, WAY JM, WINEGAR DA, CORTON JC, DOHM GL, KRAUS WE: Fatty acid homeostasis and induction of lipid regulatory genes in skeletal muscles of peroxisome proliferator-activated receptor (PPAR) alpha knock-out mice. Evidence for compensatory regulation by PPAR delta. J Biol Chem 277: 26089-26097, 2002.

MUOIO DM, NEUFER PD: Lipid-induced mitochondrial stress and insulin action in muscle. Cell Metab 15: 595-605, 2012.

NAKAMURA MT, YUDELL BE, LOOR JJ: Regulation of energy metabolism by long-chain fatty acids. Prog Lipid Res 53: 124-144, 2014.

NIELSEN S, GUO Z, JOHNSON CM, HENSRUD DD, JENSEN MD: Splanchnic lipolysis in human obesity. J Clin Invest 113: 1582-1588, 2004.

PAN DA, LILLIOJA S, KRIKETOS AD, MILNER MR, BAUR LA, BOGARDUS C, JENKINS AB, STORLIEN LH: Skeletal muscle triglyceride levels are inversely related to insulin action. Diabetes 46: 983-988, 1997.

PATKOVÁ J, ANDEL M, TRNKA J: Palmitate-induced cell death and mitochondrial respiratory dysfunction in myoblasts are not prevented by mitochondria-targeted antioxidants. Cell Physiol Biochem 33: 1439-1451, 2014.

PATTI ME, BUTTE AJ, CRUNKHORN S, CUSI K, BERRIA R, KASHYAP S, MIYAZAKI Y, KOHANE I, COSTELLO M, SACCONE R, LANDAKER EJ, GOLDFINE AB, MUN E, DEFRONZO R, FINLAYSON J, KAHN CR, MANDARINO LJ: Coordinated reduction of genes of oxidative metabolism in humans with insulin resistance and diabetes: potential role of PGC1 and NRF1. Proc Natl Acad Sci U S A 100: 8466-8471, 2003.

PETERSEN KF, BEFROY D, DUFOUR S, DZIURA J, ARIYAN C, ROTHMAN DL, DIPIETRO L, CLINE GW, SHULMAN GI: Mitochondrial dysfunction in the elderly: possible role in insulin resistance. Science 300: 1140-1142, 2003.

PETERSEN KF, DUFOUR S, BEFROY D, GARCIA R, SHULMAN GI: Impaired mitochondrial activity in the insulin-resistant offspring of patients with type 2 diabetes. $N$ Engl J Med 350: 664-671, 2004.

PICKERSGILL L, LITHERLAND GJ, GREENBERG AS, WALKER M, YEAMAN SJ: Key role for ceramides in mediating insulin resistance in human muscle cells. J Biol Chem 282: 12583-12589, 2007.

PIMENTA AS, GAIDHU MP, HABIB S, SO M, FEDIUC S, MIRPOURIAN M, MUSHEEV M, CURI R, CEDDIA RB: Prolonged exposure to palmitate impairs fatty acid oxidation despite activation of AMP-activated protein kinase in skeletal muscle cells. $J$ Cell Physiol 217: 478-485, 2008.

POSPISILIK JA, KNAUF C, JOZA N, BENIT P, ORTHOFER M, CANI PD, EBERSBERGER I, NAKASHIMA T, SARAO R, NEELY G, ESTERBAUER H, KOZLOV A, KAHN CR, KROEMER G, RUSTIN P, BURCELIN R, PENNINGER JM: Targeted deletion of AIF decreases mitochondrial oxidative phosphorylation and protects from obesity and diabetes. Cell 131: 476-491, 2007.

RANDLE PJ, GARLAND PB, HALES CN, NEWSHOLME EA: The glucose fatty-acid cycle. Its role in insulin sensitivity and the metabolic disturbances of diabetes mellitus. Lancet 281: 785-789, 1963.

RICCARDI G, GIACCO R, RIVELLESE AA: Dietary fat, insulin sensitivity and the metabolic syndrome. Clin Nutr 23: 447-456, 2004.

RITOV VB, MENSHIKOVA EV, HE J, FERRELL RE, GOODPASTER BH, KELLEY DE: Deficiency of subsarcolemmal mitochondria in obesity and type 2 diabetes. Diabetes 54: 8-14, 2005. 
RITOV VB, MENSHIKOVA EV, AZUMA K, WOOD R, TOLEDO FG, GOODPASTER BH, RUDERMAN NB, KELLEY DE: Deficiency of electron transport chain in human skeletal muscle mitochondria in type 2 diabetes mellitus and obesity. Am J Physiol Endocrinol Metab 298: E49-E58, 2010.

ROUST LR, JENSEN MD: Postprandial free fatty acid kinetics are abnormal in upper body obesity. Diabetes 42: 1567 1573, 1993.

SALVADÓ L, COLL T, GÓMEZ-FOIX AM, SALMERÓN E, BARROSO E, PALOMER X, VÁZQUEZ-CARRERA M: Oleate prevents saturated-fatty-acid-induced ER stress, inflammation and insulin resistance in skeletal muscle cells through an AMPK-dependent mechanism. Diabetologia 56: 1372-1382, 2013.

SANTOMAURO AT, BODEN G, SILVA ME, ROCHA DM, SANTOS RF, URSICH MJ, STRASSMANN PG, WAJCHENBERG BL: Overnight lowering of free fatty acids with Acipimox improves insulin resistance and glucose tolerance in obese diabetic and nondiabetic subjects. Diabetes 48: 1836-1841, 1999.

SCHAFFER JE: Lipotoxicity: when tissues overeat. Curr Opin Lipidol 14: 281-287, 2003.

SCHENK S, HOROWITZ JF: Acute exercise increases triglyceride synthesis in skeletal muscle and prevents fatty acidinduced insulin resistance. J Clin Invest 117: 1690-1698, 2007.

SCHIEBER M, CHANDEL NS: ROS function in redox signaling and oxidative stress. Curr Biol 24: R453-R462, 2014.

SCHULER M, ALI F, CHAMBON C, DUTEIL D, BORNERT JM, TARDIVEL A, DESVERGNE B, WAHLI W, CHAMBON P, METZGER D: PGC1alpha expression is controlled in skeletal muscles by PPARbeta, whose ablation results in fiber-type switching, obesity, and type 2 diabetes. Cell Metab 4: 407-414, 2006.

SEIFERT EL, ESTEY C, XUAN JY, HARPER ME: Electron transport chain-dependent and -independent mechanisms of mitochondrial $\mathrm{H} 2 \mathrm{O} 2$ emission during long-chain fatty acid oxidation. J Biol Chem 285: 5748-5758, 2010.

SENN JJ: Toll-like receptor-2 is essential for the development of palmitate-induced insulin resistance in myotubes. J Biol Chem 281: 26865-26875, 2006.

SHULMAN GI: Cellular mechanisms of insulin resistance. J Clin Invest 106: 171-176, 2000.

SPARKS LM, XIE H, KOZA RA, MYNATT R, HULVER MW, BRAY GA, SMITH SR: A high-fat diet coordinately downregulates genes required for mitochondrial oxidative phosphorylation in skeletal muscle. Diabetes $\mathbf{5 4}$ : 1926-1933, 2005.

STORLIEN LH, JENKINS AB, CHISHOLM DJ, PASCOE WS, KHOURI S, KRAEGEN EW: Influence of dietary fat composition on development of insulin resistance in rats. Relationship to muscle triglyceride and omega-3 fatty acids in muscle phospholipid. Diabetes 40: 280-289, 1991.

SZENDROEDI J, YOSHIMURA T, PHIELIX E, KOLIAKI C, MARCUCCI M, ZHANG D, JELENIK T, MÜLLER J, HERDER C, NOWOTNY P, SHULMAN GI, RODEN M: Role of diacylglycerol activation of PKC $\theta$ in lipidinduced muscle insulin resistance in humans. Proc Natl Acad Sci U S A 111: 9597-9602, 2014.

TANAKA T, YAMAMOTO J, IWASAKI S, ASABA H, HAMURA H, IKEDA Y, WATANABE M, MAGOORI K, IOKA RX, TACHIBANA K, WATANABE Y, UCHIYAMA Y, SUMI K, IGUCHI H, ITO S, DOI T, HAMAKUBO T, NAITO M, AUWERX J, YANAGISAWA M, KODAMA T, SAKAI J: Activation of peroxisome proliferator-activated receptor delta induces fatty acid beta-oxidation in skeletal muscle and attenuates metabolic syndrome. Proc Natl Acad Sci U S A 100: 15924-15929, 2003.

TURNER N, BRUCE CR, BEALE SM, HOEHN KL, SO T, ROLPH MS, COONEY GJ: Excess lipid availability increases mitochondrial fatty acid oxidative capacity in muscle: evidence against a role for reduced fatty acid oxidation in lipid-induced insulin resistance in rodents. Diabetes 56: 2085-2092, 2007.

TURNER N, KOWALSKI GM, LESLIE SJ, RISIS S, YANG C, LEE-YOUNG RS, BABB JR, MEIKLE PJ, LANCASTER GI, HENSTRIDGE DC, WHITE PJ, KRAEGEN EW, MARETTE A, COONEY GJ, FEBBRAIO MA, BRUCE CR: Distinct patterns of tissue-specific lipid accumulation during the induction of insulin resistance in mice by high-fat feeding. Diabetologia 56: 1638-1648, 2013.

TURNER N, COONEY GJ, KRAEGEN EW, BRUCE CR: Fatty acid metabolism, energy expenditure and insulin resistance in muscle. $J$ Endocrinol 220: T61-T79, 2014.

TURPIN SM, LANCASTER GI, DARBY I, FEBBRAIO MA, WATT MJ: Apoptosis in skeletal muscle myotubes is induced by ceramides and is positively related to insulin resistance. Am J Physiol Endocrinol Metab 291: E1341-E1350, 2006. 
VESSBY B, TENGBLAD S, LITHELL H: Insulin sensitivity is related to the fatty acid composition of serum lipids and skeletal muscle phospholipids in 70-year-old men. Diabetologia 37: 1044-1050, 1994.

VESSBY B, UUSITUPA M, HERMANSEN K, RICCARDI G, RIVELLESE AA, TAPSELL LC, NÄLSÉN C, BERGLUND L, LOUHERANTA A, RASMUSSEN BM, CALVERT GD, MAFFETONE A, PEDERSEN E, GUSTAFSSON IB, STORLIEN LH: Substituting dietary saturated for monounsaturated fat impairs insulin sensitivity in healthy men and women: The KANWU Study. Diabetologia 44: 312-319, 2001.

WESSELS B, CIAPAITE J, VAN DEN BROEK NMA, HOUTEN SM, NICOLAY K, PROMPERS JJ: Pioglitazone treatment restores in vivo muscle oxidative capacity in a rat model of diabetes. Diabetes Obes Metab 17: 52$60,2015$.

YUZEFOVYCH L, WILSON G, RACHEK L: Different effects of oleate vs. palmitate on mitochondrial function, apoptosis, and insulin signaling in L6 skeletal muscle cells: role of oxidative stress. Am J Physiol Endocrinol Metab 299: E1096-E1105, 2010.

YUZEFOVYCH LV, SOLODUSHKO VA, WILSON GL, RACHEK LI: Protection from palmitate-induced mitochondrial DNA damage prevents from mitochondrial oxidative stress, mitochondrial dysfunction, apoptosis, and impaired insulin signaling in rat 16 skeletal muscle cells. Endocrinology 153: 92-100, 2012. 